Fixed Point Theory, 20(2019), No. 2, 601-622

DOI: $10.24193 /$ fpt-ro.2019.2.40

http://www.math.ubbcluj.ro/ nodeacj/sfptcj.html

\title{
FIXED POINT THEORY IN TERMS OF A METRIC AND OF AN ORDER RELATION
}

\author{
ADRIAN PETRUŞEL AND IOAN A. RUS
}

Department of Mathematics, Babeş-Bolyai University, Cluj-Napoca, Romania

E-mails: petrusel@math.ubbcluj.ro iarus@math.ubbcluj.ro

Abstract. We consider a nonempty set $X$ endowed with a metric $d$ an order relation $\preceq$ and an operator $f: X \rightarrow X$, which satisfies two main assumptions:

(1) $f$ is generalized monotone with respect to $\preceq$;

(2) $f$ is a (generalized) contraction with respect to $d$ on a certain subset $Y$ of $X \times X$.

In the above terms, we will present conditions under which:

(i) $f$ has a unique fixed point in $X$;

(ii) $f$ is a Picard operator;

(iii) the fixed point problem for $f$ is well-posed;

(iv) $f$ has the Ostrowski property;

(v) $f$ has the shadowing property;

(vi) $f$ satisfies to some Gronwall type inequalities.

Then, we will apply these results to study some problems related to integral and differential equations. Several open questions are discussed.

Key Words and Phrases: Metric space, ordered set, ordered metric space, contraction, generalized contraction, increasing operator, decreasing operator, progressive operator, regressive operator, generalized monotone operator, fixed point, (weakly) Picard operator, stability, Gronwall lemma, open problem.

2010 Mathematics Subject Classification: 47H10, 34G20, 45N05, 06A06, 47H09, 47H07, 54E35, $54 \mathrm{H} 25$.

\section{REFERENCES}

[1] A. Abian, A fixed point theorem for image-intersecting mapping, Proc. Amer. Math. Soc., 73(1979), 300-302.

[2] A. Abian, A fixed point theorem for nonincreasing mappings, Boll. Un. Mat. Ital., 4(1969), 200-201.

[3] S. Abian, A.B. Brown, A theorem on partially ordered sets, with applications to fixed point theorems, Canad. J. Math., bf 13(1961), 78-82.

[4] M. Abtahi, Z. Kadelburg, S. Radenović, Fixed points and coupled fixed points in partially ordered $\nu$-generalized metric spaces, Applied General Topology, 19(2018), 189-201.

[5] R.P. Agarwal, M.A. El-Gebeily, D. O'Regan, Generalized contractions in partially ordered metric spaces, Applicable Anal., 87(2008), 109-116.

[6] R.P. Agarwal, E. Karapinar, A.-F. Roldan-Lopez-de-Hierro, Some remarks on "Multidimensional fixed point theorems for isotone mappings in partially ordered metric spaces", Fixed Point Theory Appl., 2014 2014:245, 13 pp. 
[7] A. Alam, M. Imdad, Monotone generalized contractions in ordered metric spaces, Bull. Korean Math. Soc., 53(2016), 61-81.

[8] A. Alam, Q.H. Khan, M. Imdad, Discussion on some recent order-theoretic metrical coincidence theorems involving nonlinear contractions, J. Function Spaces, 2016 Article ID 6275367, 11 pp.

[9] H. Amann, Fixed point equations and nonlinear eigenvalue problems in ordered Banach spaces, SIAM Review, 18(1976), 620-708.

[10] H. Amann, Order Structures and Fixed Points, Atti del Seminario di Analisi Funzionale e Applicazioni, University of Calabria (1977) 1-51.

[11] A. Amini-Harandi, H. Emami, A fixed point theorem for contraction type maps in partially ordered metric spaces and application to ordinary differential equations, Nonlinear Analysis: Theory, Methods \& Appl., 72(2010), 2238-2242.

[12] H. Argoubi, B. Samet, C. Vetro, Nonlinear contractions involving simulation functions in a metric space with a partial order, J. Nonlinear Sci. Appl., 8(2015), 1082-1094.

[13] H. Ben-El-Mechaiekh, The Ran-Reurings fixed point theorem without partial order: A simple proof, J. Fixed Point Theory Appl., 16(2014), 373-383.

[14] V. Berinde, Approximating fixed points of weak contractions using the Picard iteration, Nonlinear Anal. Forum, 9(2004), 43-53.

[15] V. Berinde, A. Petruşel, I.A. Rus, M.A. Şerban, The retraction-displacement condition in the theory of fixed point equation with a convergent iterative algorithm, In: Mathematical Analysis, Approximation Theory and Their Applications (Th. Rassias, V. Gupta-Eds.) Springer Optimization and Its Applications, vol. 111. Springer, Cham, 75-106, 2016.

[16] M.M. Bonsangue, F. van Breugel, J.J.M.M. Rutten, Generalized metric spaces: completation, topology and power domains, via the Yoneda embedding, Theoretical Computer Sci., 193(1998), $1-51$.

[17] A. Brøndsted, Fixed points and partial orders, Proc. Amer. Math. Soc., 60(1976), 365-366.

[18] A. Brøndsted, On a lemma of Bishop and Phelps, Pacific J. Math., 55(1974), 335-341.

[19] J. Caballero, J. Harjani, K. Sadarangani, Contractive-like mapping principles in ordered metric spaces and application to ordinary differential equations, Fixed Point Theory Appl., 2010 2010:916064, 14 pp.

[20] J. Caristi, Fixed point theorems for mappings satisfying inwardness conditions, Trans. Amer. Math. Soc., 215(1976), 241-251.

[21] S. Carl, S. Heikkilä, Fixed Point Theory in Ordered Sets and Applications, Springer Berlin, 2011.

[22] S. Chandok, M.S. Khan, T.D. Narang, Fixed point theorems in partially ordered metric spaces for generalized contractions, Azerbaijan J. Math., 5(2015), 89-96.

[23] B.S. Choudhury, P. Maity, Weak contractions on chains in a generalized metric space with a partial order, Afrika Math., 25(2014), 745-756.

[24] S.K. Chatterjea, Fixed-point theorems, C.R. Acad. Bulgare Sci. 25(1972) 727-730.

[25] C.-M. Chen, J.-C. Lee, C.-H. Chen, Fixed point theory of weak contractions in partially ordered metric spaces, J. Applied Math., 2013, Article ID 302438, 7 pp.

[26] M. M. Choban, V. Berinde, Multiple fixed point theorems for contractive and Meir-Keeler type mappings defined on partially ordered spaces with a distance, Applied General Topology, bf 18(2017), 317-330.

[27] Lj.B. Ćirić, A generalization of Banach's contraction principle, Proc. Amer. Math. Soc., 45(1974), 267-273.

[28] Lj.B. Ćirić, N. Cakić, M. Rajović, and J. S. Ume, Monotone generalized nonlinear contractions in partially ordered metric spaces, Fixed Point Theory Appl., 2008(2008), article ID 131294, $11 \mathrm{pp}$.

[29] K. Deimling, Nonlinear Functional Analysis, Springer-Verlag, Berlin, 1980.

[30] M.M. Deza, F. Deza, Encyclopedia of Distances, Springer Berlin, 2009.

[31] B.C. Dhage, Basic hybrid fixed point theorems for contractive mappings in partially ordered metric spaces, Thai J. Math., 15(2017), 721-732. 
[32] M. Dinarvand, Fixed points for generalized contractions via rational expressions in partially ordered b-metric spaces and applications to integral equations, Afrika Math., 29(2018), 175193.

[33] D. Doric, Z. Kadelburg, S. Radenovic, P. Kumam, A note on fixed point results without monotone property in partially ordered metric space, Revista de la Real Academia de Ciencias Exactas Fis. Natur. Serie A-Matematicas, 108(2014), 503-510.

[34] J. Eisenfeld, V. Lakshmikantham, Remarks on nonlinear contraction and comparison principle in abstract cones, J. Math. Anal Appl., 61(1977), 116-121.

[35] Z. Ercan, A.W. Wickstead, Banach lattices of continuous Banach lattice-valued functions, J. Math. Anal. Appl., 198(1996), 121-136.

[36] Y.-P. Fang, Z. Han, Fixed points for mixed increasing operators in ordered Banach spaces with an application, Indian J. Pure Applied Math., 33(2002), 1217-1226.

[37] B. Flagg, R. Kopperman, Continuity spaces: reconciling domains and metric spaces, Theoretical Computer Sci., 177(1997), 111-138.

[38] T.N. Fomenko, D.A. Podoprikhin, Fixed points and coincidences of mappings of partially ordered sets, J. Fixed Point Theory Appl., bf 18(2016), 823-842.

[39] M. Fréchet, Les espaces abstraits, Gauthier-Villars, Paris, 1928.

[40] M. A. Gordji, M. Ramezani, F. Sajadian, Y. J. Cho, C. Park, A new type fixed point theorem for a contraction on partially ordered generalized complete metric spaces with applications, Fixed Point Theory Appl., 2014 2014:15, 9 pp.

[41] D. Guo, Y.J. Cho, J. Zhu, Partial Ordering Methods in Nonlinear Problems, Nova Science Publishers Inc., Hauppauge, 2004.

[42] J. Harjani, K. Sadarangani, Fixed point theorems for weakly contractive mappings in partially ordered sets, Nonlinear Anal. Theory, Methods \& Appl., 71(2009), 3403-3410.

[43] J. Harjani, F. Sabetghadam, K. Sadarangani, Generalized contractions in partially ordered metric spaces and applications to ordinary differential equations, Nonlinear Anal. Theory, Methods \& Appl., 72(2010), 1188-1197.

[44] J. Harjani, K. Sadarangani, Fixed point theorems for monotone generalized contractions in partially ordered metric spaces and applications to integral equations, J. Convex Anal., 19(2012), 853-864.

[45] J. Harjani, K. Sadarangani, Fixed point theorems for cyclic weak contractions in partially ordered sets endowed with a complete metric, Carpathian J. Math., 29(2013), 179-186.

[46] S. Heikkilä, V. Lakshmikantham, Monotone Iterative Techniques for Discontinuous Nonlinear Differential Equations, CRC Press, 1994.

[47] G. Herzog, On ordinary differential equations with quasimonotone increasing right-hand side, Archiv der Mathematik, 70(1998), 142-146.

[48] T.L. Hicks and B.E. Rhoades, A Banach type fixed point theorem, Math. Japonica, 24(1979), 327-330.

[49] P. Hitzler, Generalized Metric and Topology in Logic Programming Semantics, Ph.D. Dissertation, National Univ. Ireland, 2001.

[50] J. Jachymski, The contraction principle for mappings on a metric space with a graph, Proc. Amer. Math. Soc., 136(2008), 1359-1373.

[51] M. Jleli, B. Samet, Best proximity point results for MK-proximal contractions on ordered sets, J. Fixed Point Theory Appl., 17(2015), 439-452.

[52] W.A. Kirk, B. Sims (editors), Handbook of Metric Fixed Point Theory, Kluwer Acad. Publ., Dordrecht, 2001.

[53] M.A. Krasnoselskii, Positive Solutions of Operator Equations, Noordhoff, Leyden, 1964.

[54] M.A. Krasnoselskii, Geometrical Methods in Nonlinear Analysis, Springer, Berlin, 1984.

[55] M. Marinacci, L. Montrucchio, Unique Tarski Fixed Points, Working Papers 604(2017), IGIER (Innocenzo Gasparini Institute for Economic Research), Bocconi University, Italy.

[56] G. Markowsky, Chain-complete posets and directed sets with applications, Algebra Univ., 6(1976), 53-68.

[57] Z. Mustafa, E. Karapinar, H. Aydi, A discussion on generalized almost contractions via rational expressions in partially ordered metric spaces, J. Ineq. Appl., 2014 2014:219. 
[58] H.K. Nashine, I. Altun, Fixed point theorems for generalized weakly contractive condition in ordered metric spaces, Fixed Point Theory Appl., 2011 2011:132367, 20 pp.

[59] J. J. Nieto, A. Ouahab, R. Rodriguez-Lopez, Random Fixed point theorem in partial order metric space, Fixed Point Theory Appl., 2016 2016:98, 19 pp.

[60] J.J. Nieto, R. Rodriguez-Lopez, Contractive mapping theorems in partially ordered sets and applications to ordinary differential equations, Order, 22(2005), 223-239.

[61] J.J. Nieto, R. Rodriguez-Lopez, Existence and uniqueness of fixed point in partially ordered sets and applications to ordinary differential equations, Acta Math. Sinica (English Series), 23(2007), 2205-2212.

[62] J.J. Nieto, R.L. Pouso, R. Rodriguez-Lopez, Fixed point theorems in ordered abstract spaces, Proc. Amer. Math. Soc., 135(2007), 2505-2517.

[63] J. Ombach, The simplest shadowing, Ann. Polon. Math., 58(1993), 253-258.

[64] D. O'Regan and A. Petruşel, Fixed point theorems for generalized contractions in ordered metric spaces, J. Math. Anal. Appl., 341(2008), 1241-1252.

[65] M. Păcurar, I.A. Rus, Fixed point theory for cyclic $\varphi$-contractions, Nonlinear Anal., 72(2010), $1181-1187$

[66] M. Păcurar, I.A. Rus, Some remarks on the notations and terminology in the ordered set theory, Creat. Math. Inform., 27(2018), 191-195.

[67] A. Petrusel, Fixed points Vs. coupled fixed points, J. Fixed Point Theory Appl., (2018) 20:150. https://doi.org/10.1007/s11784-018-0630-6

[68] A. Petruşel, G. Petruşel, Y.-B. Xiao, J.-C. Yao, Fixed point theorems for generalized contractions with applications to coupled fixed point theory, J. Nonlinear Convex Anal., 19 (2018), 71-88.

[69] A. Petruşel, G. Petruşel, Coupled fixed points and coupled coincidence points via fixed point theory, in: Mathematical Analysis and Applications: Selected Topics (M. Ruzhansky, H. Dutta, R.P. Agarwal - Eds.), Wiley, 2018, 661-708.

[70] A. Petrusel, I.A. Rus, Fixed point theorems in ordered L-spaces, Proc. Amer. Math. Soc., 134 (2005), 411-418.

[71] A. Petruşel, I.A. Rus, Graphic contraction principle and applications, in: Mathematical Analysis and Applications (Th. Rassias, P. Pardalos - Eds.), Springer, Berlin 2019, to appear.

[72] S.Yu. Pilyugin, Shadowing in Dynamical Systems, Springer Berlin, 1999.

[73] S. Radenović, Z. Kadelburg, Generalized weak contractions in partially ordered metric spaces, Comput Math. Appl., 60(2010), 1776-1783.

[74] A.C.M. Ran and M.C.B. Reurings, A fixed point theorem in partially ordered sets and some applications to matrix equations, Proc. Amer. Math. Soc., 132(2004), 1435-1443.

[75] I. Rival, The problem of fixed points in ordered sets, Ann. Discrete Math., 8(1980), 283-292.

[76] I.A. Rus, Fixed point theory in algebraic structures, Babeş-Bolyai Univ. Cluj, 1971 (in Romanian).

[77] I.A. Rus, Some equivalent conditions in the metrical fixed point theory, Mathematica, 23(1981), 213-218.

[78] I.A. Rus, Weakly Picard mappings, Comment. Math. Univ. Carol., 34(1993), 769-773.

[79] I.A. Rus, Generalized Contractions and Applications, Cluj Univ. Press, 2001.

[80] I.A. Rus, Picard operators and applications, Sci. Math. Japon., 58(2003), 191-219.

[81] I.A. Rus, Cyclic representation and fixed points, Annals of the Tiberiu Popoviciu Seminar, 3(2005), 171-178.

[82] I.A. Rus, Results and problems in Ulam stability of operatorial equations and inclusions, in: (Th. Rassias-ed.) Handbook of Functional Equations: Stability Theory, Springer Berlin 2014, 323-352.

[83] I.A. Rus, Some variants of contraction principle, generalizations and applications, Stud. Univ. Babeş-Bolyai Math., 61(2016) 343-358.

[84] I.A. Rus, M.-A. Şerban, Basic problems of the metric fixed point theory and the relevance of a metric fixed point theorem, Carpathian J. Math., 29(2013), 239-258.

[85] I.A. Rus, A. Petruşel, G. Petruşel, Fixed Point Theory, Cluj University Press Cluj-Napoca, 2008. 
[86] R. Saadati, S.M. Vaezpour, Monotone generalized weak contractions in partially ordered metric spaces, Fixed Point Theory, 11(2010), 375-382.

[87] B. Samet, Ran-Reurings fixed point theorem is an immediate consequence of the Banach contraction principle, J. Nonlinear Sci. Appl., 9(2016), 873-875.

[88] A.M. Samoilenko, Yu.V. Teplinskii, Countable Systems of Differential Equations, W. De Gruyter, 2003.

[89] H.H. Schaefer, Banach Lattices and Positive Operators, Springer Berlin, 1974.

[90] G. Song, Iterative technique for a integral equation in Banach space and applications, Indian J. Pure Applied Math., 32(2001), 355-360.

[91] T. Suzuki, A generalized Banach contraction principle that characterizes metric completeness, Proc. Amer. Math. Soc., 136(2008) 1861-1869.

[92] M.R. Tasković, Partially ordered sets and some fixed point theorems, Publ. Inst. Math. (Beograd), 27(1980), 241-247.

[93] M. Turinici, Contraction maps in ordered metrical structures, In: Mathematics without Boundaries (P. Pardalos, Th. Rassias - Eds.), Springer, New York, 2014, 533-575.

[94] M. Turinici, Fixed point results on abstract ordered sets, Matematiche, 49(1994), 25-34.

[95] M. Turinici, Selected Topics in Metrical Fixed Point Theory, Ed. PIM, Iaşi, 2014.

[96] , M. Turinici, Abstract comparison principles and multivariable Gronwall-Bellman inequalities, J. Math. Anal. Appl., 117(1986), 100-127.

[97] N. Van Luong, N. Xuan Thuan, Fixed point theorem for generalized weak contractions satisfying rational expressions in ordered metric spaces, Fixed Point Theory Appl., 2011 2011:46, 10 pp.

[98] H. Viet Long, N. Thi Kim Son, R. Rodriguez-López, Some generalizations of fixed point theorems in partially ordered metric spaces and applications to partial differential equations with uncertainty, Vietnam J. Math., 46(2018), 531-555.

[99] W. Walter, Ordinary differential inequalities in ordered Banach spaces, J. Diff. Eq., 9(1971), 253-263.

[100] J. Zhang, R. P. Agarwal, N. Jiang, $N$ fixed point theorems and $N$ best proximity point theorems for generalized contraction in partially metric spaces, J. Fixed Point Theory Appl., (2018) 20: 18. https://doi.org/10.1007/s11784-018-0505-x.

[101] A.D. Ziebur, Uniqueness and the convergence of successive approximations. II., Proc. Amer. Math. Soc., 16(1965), 335-340.

Received: March 15, 2018; Accepted: April 30, 2018. 
